\title{
Santri, Kelas Menengah \\ dan Politik Lokal Indonesia
}

\author{
Yulion Zalpa \\ zalpayulion@gmail.com
}

\begin{abstract}
This journal means to give an ilustration function and role of santri, as part of middle class people in Indonesia. The result of this journal shows that political dynamics of santri as the middle class always changes in every era. In colonialism era, a group of santri unite to take an independence. Meanwhile, a group of santri in post-independence era want to dominate with an idea to make Islam as the rules of nation and the government must take the policy to limit it. Consequently, a group of santri show more in practical politics in government and the other strategic position in reformation era. However, the identity of group of santri more dissolved by the interest group and another as a result from their position as middle class. Therefore, the role and identity of a group of santri as middle class show the shortage whwn the differences interest and interference of outsider precisely cause the dissension in that group of santri.
\end{abstract}

Keyword : santri, middle class, politic.

\section{Pendahuluan.}

Tulisan ini akan memberikan gambaran fungsi dan peran santri sebagai bagian dari masyarakat kelas menengah Indonesia. Kajian tentang kelas menengah di Indonesia sebetulnya bukan hal yang mudah. Hal ini dikarenakan, kelas menengah masih sangat sulit untuk disefinisikan dengan konkret. Oleh karena itu, fokus tulisan ini adalah untuk melihat politik kelompok santri di Indonesia dari prakemerdekaan hingga era reformasi, sehingga diharapkan dapat terlihat bagaimana dinamika kelompok santri sebagai kelas menengah di setiap zamannya dan pelbagai perubahannya.

Kehadiran santri dan komunitasnya, yaitu pesantren sejak awal telah memberikan sumbangsih terhadap keberadaaan Republik Indonesia. Hal ini 
dikarenakan, kelompok santri mampu memposisikan diri sebagai salah satu kelas menengah terdidik yang memiliki pengaruh bagi kondisi sosial yang ada di masyarakat, baik itu dari lingkup masyarakat terkecil hingga lingkup terbesar, yaitu negara. Adapun bentuk perjuangan kelompok santri ini berupa perlawanan fisik di masa kolonial. Sedangkan, pada masa pascakemerdekaan kelompok santri berkecimpung dalam dunia politik sebagai perwakilan di MPRS, Badan Konstuante, partai Islam dan di kementrian. Dengan kata lain, negara Indonesia dalam perjalanannya tidak dapat terlepas dari peran kelompok santri itu sendiri.

Kelompok santri memiliki strategi dalam menghadapi pelbagai persoalan sosial seperti berperan aktif dalam melawan segala bentuk kegiatan yang menyebabkan ketidakstabilan negara, serta turut terlibat menjadi bagian dari penciptaan stabilitas keamanan dan kedaulatan negara. Dengan ilmu pengetahuan dan tradisi pensantren, kelompok santri terus bergerak melangkah membangun peradaban dan kebudayaannya. ${ }^{1}$ Kenyataan tersebut adalah bagian dari hasil pendidikan awal yang ada di Indonesia, yaitu pondok pesantren. Pendidikan Islam menjadi corak khas bagi masyarakat Islam Indonesia, di samping institusi-institusi pendidikan Islam lainnya yang telah menjadi bagian pergerakan dari kelompok santri pada tingkat kebangsaan. ${ }^{2}$

Pesantren dan lembaga-lembaga pendidikan Islam menjadi basis pembekalan bagi kelompok santri untuk berkontribusi aktif bagi perkembangan kebangsaan dengan sumbangsih pemikirannya. ${ }^{3}$ Oleh karena itu, kelompok santri menempati posisi tersendiri dalam kehidupan sosial masyarakat dan negara. Kelompok santri dalam perjalanannya kemudian menjadi cendikiawan yang berpengaruh dalam kehidupan politik. Leburnya kelompok santri dan cedikiawan juga menjadi fase baru bagi perjalanan politik Indonesia. Hal tersebut mengacu pada Pemilu tahun 1955 di mana partai Islam memperoleh suara terbanyak bersanding dengan partai nasionalis (PNI) dan partai komunis (PKI). ${ }^{4}$ Namun

1. Zamakhsyari Dzhofier, Tradisi Pesantren: Memadu Modernitas untuk Kemajuan Bangsa (Yogyakarta: Pesantren Nawasea Press, 2009), 24.

2. Deliar Noer, Gerakan Modern Islam di Indonesia 1900-1945 (Jakarta: LP3ES, 1996), 45.

3. Saifuddin Zuhri, Guruku Orang-Orang Pesantren (Yogyakarta: LkiS, 2012), 41.

4. Kuntowijoyo, Runtuhnya Mitos Politik Santri: Strategi Kebudayaan dalam Dakwah Islam (Yogyakarta: Sipress, 1999), 67. 
demikian, kelompok santri kini justru memiliki kecenderungan peran yang 'sedikit' berbeda -klaim pemilik kebenaran dan perang sesama kelompok santridengan fitrahnya jauh sebelum reformasi digulirkan.

Analisis kelas dalam pemikiran Max Weber akan dijadikan landasan teori dalam tulisan ini. Pemikiran Weberian dalam pembentukan kelas tidak hanya didasari oleh penguasaan alat produksi, akan tetapi juga kegiatan konsumtif, status sosial, kewibawaan dan daya tawar dalam pertukaran pasar. Di samping itu, pemikiran Weberian lebih memfokuskan pada realitas empiris yang mikro dan majemuk, sehingga lebih mudah diteliti dan diuji. ${ }^{5}$ Jika dibanding dengan gagasan Marxian yang terlalu makro dan kajiannya yang terlalu luas serta wataknya yang terlalu dikotomis dan deterministik, pemikiran Weberian lebih tepat untuk menjelaskan konsep menengah dalam realita empiris. Selain itu juga hasil daei dialektika yang selama ini terjadi antara pemikiran Weberian dan Marxian dalam pembagian kelas ditemukan bahwa dalam "kapitalisme" mutakhir terdapat sejumlah aset produktif yang layak sebagai modal, yaitu yaitu modal manusiawi, modal simbolik/kultural dan diskursus budaya kritis selain dari modal ekonomi. ${ }^{6}$ Dengan demikian, tulisan ini akan lebih mudah dalam mengidentifikasi gerakan dan peran kelas menengah khususnya kelompok santri.

\section{Kelompok Santri sebagai Kelas Menengah}

Santri merupakan orang yang belajar di pondok pesantren. Santri dalam tradisi pondok pesantren mempunyai dua kategori. Pertama, santri kalong yaitu santri yang dapat pulang-pergi dan tidak bermukim di pesantren. Mereka ini adalah para santri yang berasal dari daerah sekitar pondok pesantren. Kedua, santri mukim di mana santri yang bermukim dilingkungan pondok pesantren dan menempati pondok yang telah di sediakan oleh pesantren. ${ }^{7}$ Namun demikian, pengertian santri ini secara luas dapat dikatakan sebagai setiap orang yang pernah

5. Ariel Heryanto, Kelas Menengah yang Majemuk dalam Kelas Menengah Bukan Ratu Adil (Yogyakarta: Tiara Wacana, 1999), 7.

6. Ibid, 8 .

7. Zamakhsyari Dzhofier, Tradisi Pesantren Stusdi Pandangan Hidup Kiyai dan Visinya Mengenai Masa Depan Indonesia (Jakarta: LP3ES, 2011), 59. 
berguru kepada ustaz, baik itu sebagai pendengar, pengikut, pelajar yang menetap, dan yang pernah berinteraksi dengan ustaz dalam kurun waktu tertentu. bertahuntahun. $^{8}$

Santri sebagai pelajar yang datang dari berbagai penjuru nusantara mempunyai tanggungan untuk membiayai proses belajarnya. Akan tetapi, kondisi perekonomian mayoritas santri memadai tertutama di masa-masa sebelum kemerdekaan. Hal ini menunjukkan bahwa dengan kondisi ekonomi, tingkat keilmuan santri punyai, lambang serta simbol-simbol yang mereka pergunakan mempunyai karakter tersendiri. Kemudian, secara umum keadaan demikian membuat mereka menjadi kelas tersendiri dalam sosial masyarakat Indonesia. setidaknya hingga pertengahan abad ke-20.

Kelompok santri perlu dipahami tidak hanya berstatus sebagai pelajar di pesantren semata, namun para ustaz, ulama, serta cendikiawan pun menjadi produk pesantren merupakan bagian dari jejaring dan masuk dalam kategori kelompok santri. Santri sebagai kelompok kelas menengah mempunyai modal penting seperti kekayaan (ekonomi), kekuasaan dalam lapisan masyarakat, kehormatan, dan pengetahuan. Dengan modal itulah kelompok santri menjadi elemen penting dalam menggerakkan dan memobilisasi masyarakat serta turut serta dalam kehidupan bernegara Indonesia. ${ }^{9}$

Posisi dan tindakan yang dilakukan oleh kelompok santri sebagai kelas menengah relevan dengan yang dinyatakan oleh Weber. Kelas menengah ini dipengaruhi oleh konsep daya, tindakan komunal serta aksi sosial. Pertama, yang dimaksudkan daya, yaitu kemampuan kelompok untuk mewujudkan kehendak bersama. Kedua, tindakan komunal muncul dikarenakan kepercayaan bersama dan rasa memiliki yang mengikat masing-masing anggota kelompok. Ketiga, aksi sosial muncul dikarenakan adanya penyesuaian rasional dalam kepentingan

8. Ahmad Baso, Pesantren Studies: Kosmopolitanisme Peradaban Kaum Santri di Masa Kolonial (Jakarta: Pustaka Afied, 2012), 43.

9. Saifuddin Zuhri, Berangkat dari Pesantren (Yogyakarta: LkiS, 2013), 32. 
masing-masing anggota bukan dalam tujuan bersama, akan tetapi dalam pengakuan kepentingan bersama. ${ }^{10}$

\section{Tindakan Politik Kelompok Santri}

\section{a) Kelompok Santri Pra dan Pasca Kemerdekaan}

Kelompok santri di masa pra kemerdekaan memegang teguh ajaran Islam sehingga gerakannya begitu dinamis dan sulit untuk dapat dijinakkan oleh Belanda maupun Jepang. Oleh karena itu, kelompok santri ini melawan penjajahan yang tak mungkin dihadapi dengan perlawanan fisik melalui pemikiran-pemikiran dan kekuatan organanisasi, seperti halnya dalam Sarikat Islam (1911), Nahdhatul Ulama (1926), Muhammadiyah (1912), dll. Namun demikian, selain kelompok tersebut masih terdapat organisasi lainnya yang berdiri pada masa itu, yaitu Jamiat Khair (1905), Persyarikatan Ulama (1911), Persatuan Islam (1920), Partai Arab Indonesia (1934). Untuk mempersatukan pemikiran kelompok santri guna menghadapi penjajahan, organisasi Muhammadiyah dan Nadhatul Ulama bersama-sama menjadi sponsor pembentukan suatu federasi Islam yang baru yang disebut sebagai Majelis Islam Ala Indonesia (majelis Islam tertinggi di Indonesia) yang disingkat MIAI yang didirikan di Surabaya pada tahun 1937.

Banyaknya kelompok santri yang ada di Indonesia justru difasilitasi oleh pemerintahan Jepang dan menguntungkan kelompok santri itu sendiri. Adapun bentuk pranata sosial yang dibentuk oleh Jepang yaitu: Shumubu (Kantor Urusan Agama yang menggantikan Kantor Urusan Pribumi zaman Belanda yang dipimpin oleh Hoesein Djayadiningrat pada 1 Oktober 1943). Kemudian, Masyumi, (Majelis Syura Muslimin Indonesia) menggantikan MIAI yang dibubarkan pada bulan oktober 1943 di mana tujuan didirikannya adalah untuk memperkokoh persatuan kelompok santri di Indonesia dan untuk meningkatkan bantuan peperangan Jepang. Terakhir, yaitu Hizbullah (Partai Allah atau Angkatan Allah) yang merupakan semacam organisasi militer untuk santri-santri yang dipimpin 
oleh Zainul Arifin - organisasi inilah yang menjadi cikal bakal Tentara Nasional Indonesia (TNI). ${ }^{11}$

Kelompok santri pascakemerdekaan mulai menyibukkan diri dengan politik praktis dengan mendirikan partai politik guna mendukung sistem pemerintahan yang demokratis. Partai politik juga berfungsi untuk memudahkan umat Islam pada umunya menyampaikan aspirasinya dan memudahkan penyatuan umat Islam dalam mendukung perjuangan kemerdekaan Indonesia, salah satunya adalah Masyumi yang dibentuk dalam Muktamar Islam Indonesia pada tanggal 78 Oktober 1945. Dalam muktamar tersebut diputuskan bahwa Masyumi menjadi partai satu-satunya yang memperjuangkan nasib politik kelompok santri dan umat Islam di Indonesia sehingga partai Islam yang lain sudah tidak diakui lagi.

Berdirinya Masyumi ini memberikan harapan atas kepentingan kelompok santri, khususnya tentang gagasan mendirikan negara Islam dan penerapan syariat Islam di Indonesia. Namun demikian, Masyumi mengalami perpecahan antara NU dan Muhammadiyah yang didasari oleh persaingan perebutan posisi dalam partai dan pemerintahan. Dalam peperangan tersebut, NU lebih banyak mengalami kekalahan dan kemudian memutuskan untuk keluar dari Masyumi di tahun 1952 yang sebelumnya PSII juga telah lebih dahulu keluar pada tahun 1947.

Corak menonjol yang disuarakan oleh kelompok santri itu sendiri adalah upaya penerapan syariat Islam di Indonesia dengan jalur politik dan kekuasaan. Terbentuknya Departemen Agama pada tahun 1946 merupakan ekpresi dukungan unsur pemerintahan pada waktu itu atas pentingnya syariat Islam. Perjuangan sangat strategis sebagai upaya penerapan syariat Islam terjadi ketika perdebatan tentang dasar negara yang mana kelompok santri menginginkan Islam sebagai dasar negara, sedangkan kelompok nasionalis menginginkan Pancasila sebagai dasar negara. Namun demikian, perdebatan tentang syariat Islam tersebut sudah mulai nampak ketika pemerintah Jepang membentuk BPUPKI pada tanggal 24 April 1945 sebagai perwujudan janji pemerintah Jepang atas kemerdekaaan Indonesia.

11. Harry J. Benda, Bulan Sabit Matahari Terbit: Islam Indonesia dalam Masa Pendudukan Jepang (Jakarta: Pustaka Jaya, 1980), 26. 
Perdebatan lain tentang kelompok santri ini juga terbelah menjadi dua kubu, yaitu kubu nasionalis muslim dan nasionalis sekuler. Perdebatan itu bermuara pada dua pandangan, pertama, kelompok santri pendukung dasar Islam hendak mengaplikasikan seluruh isi syariat Islam yang ada pada Al-Qur'an. Kedua, kelompok santri nasionalis sekuler yang nampaknya hanya ingin mengurung Islam dalam sebuah sangkar 'kepentingan pribadi'. Namun demikian, kelompok nasionalislah yang menggagalkan dan mengalahkan kehendak kelompok santri tersebut. Adanya rasa kecewa di kubu santri memunculkan letupan-letupan yang masih dirasakan hingga saat ini. Salah satu bentuk letupan kekecewaan yang disinyalir oleh segelintir orang adalah lahirnya pergerakan (pemberontakan) untuk menjadikan negara Indonesia sebagai negara Islam seperti DI/TII-nya Kartosuwirjo di Jawa Barat, Kahar Muzakar di Sulawesi Selatan dan Sulawesi Tenggara serta Daud Beureuh di Aceh. ${ }^{12}$

\section{b) Kelompok Santri Orde Lama}

Wakil Presiden Mohammad Hatta pascaproklamasi kemerdekaan atau tepatnya pada tanggal 3 November 1945 mengeluarkan sebuah Maklumat Pemerintah tentang hak hidup partai-partai politik di Indonesia. Partai-partai tersebut diharapkan sudah berdiri sebelum dilangsungkan pemilihan anggota badan perwakilan rakyat pada Januari 1946. Pada saat inilah, kekuatan politik kelompok santri di era Orde Lama terlihat. Kelompok santri langsung bereaksi dengan seruan pemerintah dengan menyelenggarakan Kongres Umat Islam Indonesia pada tanggal 7-8 Nopember 1945 di Yogyakarta. Partai Masyumi sebagai partai resmi kelompok santri, yaitu Muhammadiyah, Nahdlatul Ulama, Perserikatan Umat Islam dan Persatuan Umat Islam, kemudian bergabung juga Persatuan Islam (Bandung 1948), Al-Irsyad (Jakarta, 1950), termasuk partai-partai kecil lainnya yang ada di daerah-daerah, seperti Al-Jamiyatul Wasliyah (Sumatera Utara), Persatuan Ulama Seluruh Aceh (PUSA 1949-1953).

Sebagian besar kelompok santri yang mendukung gagasan negara Islam tidak menyerah begitu saja, perjuangan wakil-wakil santri di dalam sidang 
Konstitutante hasil pemilu 1955 berusaha untuk mengegolkan kembali gagasan negara Islam, khususnya dalam hubungannya dengan gagasan bahwa Islam harus dijadikan sebagai dasar negara Indonesia dengan dalih mayoritas penduduknya beragama Islam. Menyikapi hal tersebut ialah M. Natsir yang menegaskan bahwa Indonesia hanya memiliki dua pilihan, yaitu sekularisme atau paham keagamaan (dini) sehingga Pancasila tetap menjadi dasar negara Indonesia sebab tidak bercorak sekuler dan mengakui wahyu sebagai sumbernya.

Masyumi sebagai partai kelompok santri justru menunjukkan indikator terjadinya perpecahan dalam politik praktis kelompok santri itu sendiri dan semakin melemahnya Masyumi sebagai kekuatan politik Islam pada umumnya. NU kemudian menjadi partai politik (1952), dan pada pemilu 1955 NU muncul sebagai partai terbesar nomor tiga sesudah PNI dan Masyumi dengan meraih 18,4 persen suara atau 45 kursi dalam parlemen. ${ }^{13}$ Namun demikian, kekuatan politik umat Islam pada masa Orde Lama banyak dirugikan oleh kebijakan Soekarno. Khususnya yang berkaitan dengan sistem Demokrasi Terpimpin. Hal ini dikarenakan, sistem demokrasi terpimpin memberikan keleluasaan lebih besar kepada Partai Komunis Indonesia (PKI) untuk bergerak dan menguasai panggung politik nasional dan juga kebijakan Soekarno untuk membubarkan Masyumi pada Agustus 1960. Presiden Soekarno dalam pidatonya pada 17 Agustus 1959 mengatakan bahwa butir-butir pokok demokrasi Terpimpin dalam dua kategori, yaitu (1) Setiap orang diwajibkan untuk berbakti kepada kepentingan umum, masyarakat dan negara; (2) Setiap orang mendapat penghidupan layak dalam masyarakat, bangsa dan negara. Dua kategori ini menjelaskan sasaran yang hendak dicapai oleh sistem tersebut sehingga perkembangan kekuatan politik kelompok santri pada masa Orde Lama ini justru mengkristal menjadi poros ideologi dan partai.

\section{c) Kelompok Santri Orde Baru}

Perubahan kondisi perpolitikan negara Indonesia juga ikut dimotori oleh kelompok santri dengan penolakan terhadap komunisme. Dalam usaha menekan 
kekuatan politik PKI dan para simpatisannya, kekuatan politik kelompok santri tampil sebagai partner utama ABRI. Peran kelompok santri sebagai pelaku paling menentukan dalam grand coalition "pengganyangan" PKI antara lain terlihat dari hampir keseluruhan kesatuan-kesatuan aksi seperti KAP Gestapu, KAMI dan KAPI yang pucuk pimpinannya dipegang oleh tokoh-tokoh organisasi kelompok santri. Partnership militer dengan kekuatan politik kelompok santri terus berlanjut setelah pembubaran PKI. Hal ini dikarenakan, militer membutuhkan kekuatan kelompok santri untuk menekan Soekarno turun dari kekuasaannya.

Besarnya pengaruh dan peranan kelompok santri untuk membubarkan PKI meruntuhkan Orde Lama yang berarti memiliki andil besar dalam proses kelahiran Orde Baru telah mempengaruhi persepsi para pemimpin politik kelompok santri dalam menentukan strategi selanjutnya. Adapun strategi tersebut adalah untuk mempengaruhi kondisi psikologis elit santri dalam merehabilitasi instrumen politik partai kelompok santri dan semangat umum strategi pengedepanan perjuangan kelompok santri melalui partai Islam dan mengikuti pemilihan umum. Dalam sidang MPRS muncul kembali kehendak dari kelompok santri yang diwakili oleh kelompok NU dan Parmusi untuk menjadikan negara Indonesia sebagai negara berideologi Islam, pemimpin Islam serta kewajiban menjalankan syari'at Islam bagi para pemeluknya. Persoalan ini muncul di tahun 1966, 1967, 1968, dan 1969. ${ }^{14}$

Strategi kaum santri untuk memfokuskan artikulasi politiknya melalui partai Islam ternyata berbenturan dengan strategi stabilisasi politik negara yang secara ketat membatasi politik kepartaian. Perbedaan tajam logika strategi politik kelompok santri dengan negara ORBA diperuncing oleh dominasi kelompok 'abangan' dan Kristen Katolik di berbagai sektor negara. Dominasi kelompok minoritas yang paling menonjol peranannya dalam membentuk visi negara justru menyudutkan kelompok santri banyak dilakukan oleh orang-orang di lingkaran Ali Moertopo dengan "Kelompok Tanah Abang” atau CSIS-nya.

14. Abd. Munir Mulkan, Runtuhnya Mitos Politik Santri; Strategi Kebudayaan dalam Dakwah Islam (Yogyakarta: Sipress, 1999), 58. 
Pergeseran hubungan kekuatan politik kelompok santri dengan Orde Baru dikonfrontasi oleh kebangkitan gerakan pemikiran baru yang mempengaruhi perubahan statregi kelompok santri dan merosotnya pamor politik partai kelompok santri serta meningkatnya penetrasi gerakan Islam ke dalam tubuh negara. Dalam gerakan pemikiran baru tersebut semakin mendapat ruang gerak lebih luas dalam menentukan agenda perpolitikan kelompok santri setelah kepemimpinan PPP terus-menerus mengalami kemerosotan pengaruh dalam wacana politik nasional akibat kemelut internal yang parah di sekitar Pemilu 1982. Demikian halnya dengan pemberlakuan UU No. 3 dan $8 / 1985$ terutama pemberlakuan azas tunggal telah memberikan peluang penganut pemikiran baru untuk mengekspresikan gagasan-gagasan politiknya dengan melakukan rekonsiliasi secara intensif dengan pemerintah Orde Baru. ${ }^{15}$

Bangkitnya gerakan pemikiran baru pada prinsipnya menghendaki dilakukanya reorentasi strategi perjuangan kelompok santri. Dalam dimensi vertikal, kalangan penggagas gerakan pemikiran baru menyerukan para tokoh kelompok santri untuk menerapkan pendekatan politik baru yang lebih menekankan pada lobbying dan bekerja dari dalam negara. Dalam perkembangannya, dinamika kekuatan kelompok santri pascapemberlakuan azas tunggal memasuki paruh kedua dekade 1980-an semakin memberikan ruang gerak lebih luas bagi kalangan elit kelompok santri yang bersedia menjadi anggota Fraksi Karya Pembangunan di MPR dan memberikan persetujuan terhadap beberapa materi GBHN yang dalam sidang MPR sebelumnya sangat ditentang keras oleh kalangan kelompok santri pada saat itu. Perbagai terobosan kelompok santri memberi sinyal bagi pemerintahan Soeharto bahwa kelompok santri pada dasarnya bersedia mengambil sikap lebih moderat dan dan dapat bekerja sama dengan harapan semakin dilibatkan dalam sharing power dan pengambilan kebijakan -meskipun pada awalnya kelompok santri ini justru dijadikan alat oleh Soeharto melengserkan Orde Lama. 


\section{d) Kelompok Santri Era Reformasi}

Reformasi 1998 silam memberikan kebebasan seluas-luasnya bagi rakyat untuk memperoleh hak-haknya yang selama ini dipasung, khususnya mendirikan partai politik sebagai salah satu implementasi sistem demokrasi dan perubahan. Tindak lanjut dari legalisasinya pendirian partai politik memunculkan 181 partai yang mendaftarkan diri untuk pemilu 1999. Akan tetapi, partai yang lolos verifikasi oleh Komisi Pemilian Umum hanya 48 peserta dan 8 diantaranya merupakan partai kelompok santri. Namun demikian, presentasi suara untuk partai komunitas santri hanya $18 \%$ atau sekitar 86 kursi di parlemen yang diwakili oleh partai PPP, Partai Bulan Bintang, Partai Keadilan, Partai Kebangkitan Ummat, Partai Nadhatul Ummah, PSI dan Masyumi. Hal tersebut berbeda dengan Partai yang berbasis massa Islam seperti NU dan Muhammadiyah dengan perolehan suara keseluruhan 37 persen yang mana di parlemen, PAN dengan 34 kursi dan PKB dengan 51 kursi.

Partai-partai Islam dan yang berbasis massa Islam sering menuai perbedaan pendapat di parlemen, seperti pengusulan 7 kata dalam Piagam Jakarta untuk dicantumkan lagi dalam pasal 29 ayat 1 yakni Ketuhanan Yang Maha Esa dengan kewajiban menjalankan syariat Islam bagi Pemeluknya. Uniknya, dalam pandangan politik praktis partai-partai Islam mampu menyamakan pendapat, contohnya saat Abdurrahman Wahid terpilih sebagai presiden Republik Indonesia dalam sidang DPR 1999. ${ }^{16}$ Pada pemilu ditahun 2004 dan 2009 hasilnya pun hampir bernada sama. Partai komunitas santri yang digadang-gadang akan memenangkan pemilihan justru memperoleh hasil lebih sedikit dibandingkan pada pemilu 1999, yaitu 171 kursi di parlemen turun menjadi 166 kursi. Hal tersebut mendorong asumsi bahwa partai komunitas santri sebagai salah satu kekuatan politik belum sepenuhnya mewakili komunitas santri itu sendiri. Kekuatan politik kelompok santri sebetulnya bisa solid atau bahkan akan ditakuti oleh lawan-lawan politiknya apabila terdapat rasa persatuan. Hal tersebutlah belum terlihat dikalangan elit politik, khususnya partai politik yang mengatasnamakan kelompok

16. Zamaksyari Dzhofier, Tradisi Pesantren: Memadu Modernitas untuk Kemajuan Bangsa (Yogyakarta:Pesantren Nawasea Press, 2009). 55-58. 
santri. Oleh karena itu, selama masa reformasi kekuatan kelompok santri dikancah perpolitikan nasional belum signifikan yang ditambah lagi adanya institusiinstitusi politik hanya menguntungkan kelompok tertentu dan memungkinkan terpecah-belahnya kelompok santri itu sendiri.

Kemunculan partai-partai kelompok santri tidak semuanya berimplikasi negatif. Hal ini dikarenakan, mulai berkembangnya repolitisasi politik kelompok santri setelah dimarjinalkan rejim Orde Baru. Politik kelompok santri secara substansial merupakan penghadapan Islam dengan kekuasan dan negara yang melahirkan sikap dan perilaku (political behavior) serta budaya politik (political culture) yang berorientasi pada nilai-nilai Islam. Sikap perilaku serta budaya politik yang memakai kata sifat Islam. Selain itu juga dampak besar lainnya adalah kaburnya polarisasi kaum santri. Kaum santri bergerak dengan basis kekuatan sendiri, dengan modal dukungan yang tidak hanya dari kaum elit santri atau para ulama semata, tapi juga dari berbagai pihak lainnya yang memiliki kesamaan kepentingan dan ide seperti halnya menebarkan sikap toleransi terhadap kelompok-kelompok minoritas yang ada di Indonesia ini.

\section{Penutup}

Kelompok santri sebagai kelas menengah dan bagian sejarah perpolitikan Indonesia adalah rangkaian yang tidak dapat dipisahkan. Kelompok santri bersatu dalam satu kepentingan besama untuk membebaskan bangsa Indonesia dari tangan kolonialisme Belanda dan Jepang. Namun demikian, pascakemerdekaan justru berkendak untuk menguasainya dengan usulan Islam sebagai dasar negara. Dengan kata lain, kelompok santri ini justru dimanfaatkan oleh Orde Baru dalam melengserkan Soekarno dengan isu komunismenya. Sedangkan, kelompok santri semakin menampakkan diri dalam percaturan politik praktis dalam pemerintahan posisi strategis lainnya pada era reformasi. Meskipun harus diakui bahwa identitas kelompok santri semakin melebur oleh kepentingan golongan dan kelompok semata sehingga pengaruh yang diakibatkan oleh kelompok santri ini sebagai akibat dari posisinya sebagai kelas menengah Indonesia. Peran santri dan identitas mereka sebagai kelas menengah dalam panggung politik Indonesia senantiasa 
dinamis, perubahan demi perubahan dialami seiring dengan konteks zaman masing-masing, perbedaan kepentingan, intervensi dari pihak luar menjadi salah satu penyebabnya. Akan tetapi yang terpenting adalah sebagai kelas menengah, kelompok santri mampu memposisikan peran mereka sebagai perantara kelas dibawahnya dan kelas atas.

\section{Daftar Pustaka}

Baso, Ahmad. Pesantren Studies: Kosmopolitanisme Peradaban Kaum Santri di masa Kolonial. Jakarta: Pustaka Afied, 2012.

Benda, Harry J. Bulan Sabit Matahari Terbit: Islam Indonesia dalam Masa Pendudukan Jepang. Jakarta: Pustaka Jaya, 1980.

Dzhofier, Zamaksyari. Tradisi Pesantren: Memadu Modernitas untuk Kemajuan Bangsa. Yogyakarta:Pesantren Nawasea Press, 2009.

. Tradisi Pesantren Studi Pandangan Hidup Kiyai dan Visinya Mengenai Masa Depan Indonesia. Jakarta: LP3ES, 2011.

Giddens, Anthony. Kapitalisme dan Teori Sosial Modern. Suatu Analisis Karya Tulis Marx, terj. Soeheba Kamadibrata. Jakarta: UI Press, 1986.

Hadijaya (editor), Kelas Menengah Bukan Ratu Adil. Yogyakarta: Tiara Wacana, 1999.

Kuntowijoyo. Runtuhnya Mitos Politik Santri: Strategi Kebudayaan dalam Dakwah Islam. Yogyakarta: Sipress, 1999.

Mulkan, Abd. Munir. Runtuhnya Mitos Politik Santri; Strategi Kebudayaan dalam Dakwah Islam. Yogyakarta: Sipress, 1999.

Noer, Dalier. Gerakan Modern Islam di Indonesia 1900-1945. Jakarta: LP3ES, 1996.

Zuhri, Saifuddin. Berangkat dari Pesantren. Yogyakarta: LkiS, 2013.

. Guruku Orang-Orang Pesantren. Yogyakarta: LkiS, 2012. 